\title{
Sources of Teacher Self-Efficacy in Teacher Education for Inclusive Practices
}

\author{
Bárbara Amaral Martins ${ }^{1}$ \\ Miguel Claudio Moriel Chacon ${ }^{2}$
}

\begin{abstract}
Self-efficacy concerns the individual's beliefs in their ability to perform certain activities and influences the level of determination and effort involved. This study aimed to investigate whether teacher education courses for inclusive practices, involving sources of self-efficacy, produce effects on teacher self-efficacy. Thirty-six teachers participated; part of them took part in the course on inclusion of students with intellectual disabilities and the others on inclusion of students with giftedness. The courses stood out for their indissolubility between theory and practice and joint reflexive analysis of videos with successful inclusive educational situations, in order to involve social persuasion and vicarious experiences. The effects of the teacher education were evaluated with the Teacher Efficacy for Inclusive Practices Scale, in the versions Intellectual Disability and Giftedness. The results revealed that there was an increase in teachers' self-efficacy, in order to indicate the potential of the sources of self-efficacy addressed in teacher education.
\end{abstract}

Keywords: special education, inclusive education, self-efficacy, teacher education

\section{Fontes de Autoeficácia Docente na Formação de Professores para Práticas Inclusivas}

\begin{abstract}
Resumo: A autoeficácia diz respeito às crenças do indivíduo em suas capacidades para realizar determinadas atividades e influencia seu nível de determinação e esforço. Este estudo teve como objetivo investigar se cursos de formação para práticas inclusivas que envolvem fontes de autoeficácia produzem efeitos na autoeficácia docente. Participaram 36 professores, parte deles realizou curso sobre inclusão de estudantes com deficiência intelectual, os demais realizaram curso sobre inclusão de estudantes com altas habilidades/superdotação. Os cursos primavam pela indissociabilidade entre teoria e prática e análise reflexiva conjunta acerca de vídeos com situações educacionais inclusivas bem-sucedidas de modo a envolver persuasão social e experiências vicárias. Os efeitos da formação foram avaliados a partir da Escala de Eficácia Docente para Práticas Inclusivas nas versões Deficiência Intelectual e Altas Habilidades/Superdotação. Os resultados revelaram que houve aumento na autoeficácia dos professores de modo a indicar as potencialidades das fontes de autoeficácia abordadas na formação docente.
\end{abstract}

Palavras-chave: educação especial, educação inclusiva, autoeficácia, formação de professores

\section{Fuentes de Autoeficacia Docente en la Formación del Profesorado para Prácticas Inclusivas}

\begin{abstract}
Resumen: La autoeficacia se refiere a las creencias del individuo en su capacidad para realizar ciertas actividades e influye en el nivel de determinación y esfuerzo involucrados. Este estudio tuvo como objetivo investigar si los cursos de capacitación para prácticas inclusivas que involucren fuentes de autoeficacia producen efectos sobre la autoeficacia docente. Participaron 36 profesores; una parte realizó un curso sobre la inclusión de estudiantes con discapacidad intelectual y los demás, sobre la inclusión de estudiantes con superdotación. Los cursos se destacaron por su inseparabilidad entre la teoría y la práctica y el análisis reflexivo conjunto de videos con situaciones educativas inclusivas exitosas para involucrar la persuasión social y las experiencias vicarias. Los efectos de la formación se evaluaron con la Escala de Eficacia Docente para Prácticas Inclusivas, en las versiones Discapacidad Intelectual y Superdotación. Los resultados revelaron que hubo un aumento en la autoeficacia de los docentes, con el fin de indicar el potencial de las fuentes de autoeficacia abordadas en la formación docente.
\end{abstract}

Palabras clave: educación especial, educación inclusiva, autoeficacia, formación de profesores

\footnotetext{
'Universidade Federal de Mato Grosso do Sul, Corumbá-MS, Brazil

${ }^{2}$ Universidade Estadual Paulista Júlio de Mesquita Filho, Marilia-SP, Brazil

Correspondence address: Bárbara Amaral Martins. Universidade Federal de Mato Grosso do Sul. Avenida Rio Branco, 1270, Corumbá-MS, Brazil. CEP 79.304-902. Email: barbara.martins@ufms.br
}

Inclusive education demands that schools be able to adapt themselves to meet the needs of any student, also including those ones belonging to the Special Education, and promoting their learning and participation. Brazilian legislation 
establishes that Special Education embraces students with disabilities, giftedness and global developmental disorders (Law No. 9394/1996).

Providing high-quality education for all is a task that depends on the quality of teacher education (Garcia, 2016), since teachers are responsible for planning and implementing pedagogical strategies that are appropriate to each student's learning process; as it is not possible to have a differentiated training for those teachers who will work with this specific public (special education) and those who will not (regular education), and considering that, even if there are expert and generalist teachers, both must work collaboratively (Capellini \& Zerbato, 2019; Silva \& Silva, 2015).

Such a shift in the paradigm confronts the view of the classroom as a standardization space and generates a sense of unpreparedness; mainly because it is a group of students whose educational needs demand differentiated responses. With the sense of inadequacy, school staff tends to cling to a clinical discourse, which reinforces the organic aspects and difficulties faced by students (Silva \& Ribeiro, 2017).

Faria and Camargo (2018) conducted a systematic review study on the emotions of teachers from Elementary School 1 in relation to school inclusion and found that the most frequently mentioned emotions/feelings are: distress, helplessness, insecurity, impotence, isolation, and fear; generally associated with teacher unpreparedness. This situation of unpreparedness can arouse feelings of insecurity and helplessness in educators, which may be related to the constant clamor of teachers for Special Education caregivers and experts in the schools (Matos \& Mendes, 2015).

It is understood that the articulation between the work of generalist and specialist teachers is indispensable, in addition to certain students who require the accompaniment of a caregiver, whose intervention is not pedagogical but is focused on the accomplishment of activities of daily living. What cannot happen is the attempt to transfer the responsibilities of the regular classroom teacher to other teachers/professionals (Matos \& Mendes, 2015; Barbosa, 2018) an attitude which is possibly linked to feelings of insecurity and incapacity triggered by lack of adequate training.

In the same way, when training is exclusively theoretical, lacking associations with educational reality, the professional cannot always associate the theoretical foundation studied with the practice (Miranda, Dall'Acqua, Heredero, Giroto, \& Martins, 2013) - especially during the initial training, when teaching is not yet a job - which helps us to understand why many educators believe that the academic training they have is something that distances themselves from everyday school life. Moreover, the authors emphasize that the teacher is an agent of human development, committed to others, which means that the predominantly theoretical training does not constitute the necessary basis for the performance of this professional.

In addition to curricular knowledge, teacher education should ensure the development of reflection and conduction skills of the educational process, which are based on the educator's conceptions and responsibility with their social function (Nozi \& Vitaliano, 2017).
Effecting inclusive education requires changes in pedagogical practices and the search for new strategies so that everyone can participate and learn together, increasing the quality of educational relations. However, it is incoherent to expect the educator to teach in a way that they did not learn, as well as to imagine that, during the initial training, all the contents required by the teaching practice will be exhausted (Heredero, 2016). This means that continuing education must be permanently present so that it provides the subsidies desired by the teachers in understanding and intervening in the difficulties found in daily school life.

The benefits of teacher education to inclusive practices are linked to the strengthening of teachers' self-efficacy beliefs (Bzuneck, 2017).

The concept of self-efficacy refers to the individuals' beliefs about their abilities to organize and execute the actions necessary to produce certain achievements (Bandura, 1997). Teaching self-efficacy, in particular, corresponds to the educator's judgment about their abilities to promote learning and engagement of their students, even if they present some difficulty (Tschannen-Moran \& Woolfolk Hoy, 2001).

The higher the self-efficacy, the greater the amount of effort and persistence expended in a given task, since people tend to avoid activities for which they believe they do not have the necessary skills, preferring to devote themselves to those in which they consider to be competent to achieve success (Bandura, 1997, Navarro, 2007).

Teacher self-efficacy, besides being related to the didactic options and the way in which the teacher conducts the educational process, is also associated with the academic success of the students, and their aspirations and conceptions about themselves (Bandura, 1997), being one of the most impressive teaching characteristics on student performance (Navarro, 2007).

The difficulties in the teaching-learning process are understood by teachers, with strong beliefs in their teaching capacities, as surmountable obstacles, from ingenuity and extra effort, instead of placing responsibility on students for their failure in learning (Bandura, 1997). This is an important differential factor, since teachers with high self-efficacy tend to encourage the interests and autonomy of students, attributing to them the centrality of the educational process and perceiving their difficulties as susceptible to overcoming from extra support; they generate a favorable atmosphere to the learning, plan and analyze their teaching, facing academic problems (Navarro, 2007).

On the other hand, educators with low self-efficacy are resistant to innovations, more likely to restrict students' freedom, maintaining an authoritarian stance and prioritizing punitive disciplinary strategies; to avoid efforts to solve stressful problems; to compromise less with didactic activities; and to present a pessimistic view on the educability of students, often blamed when learning does not occur in an expected way (Bandura, 1997; Buzuneck, 2008; Navarro, 2007).

The main sources of teacher self-efficacy and general self-efficacy are the same: mastery experiences, vicarious 
experiences, verbal or social persuasion, and physiological and affective states (Bandura, 1997). In this study, we emphasize the potentialities of vicarious experiences, in learning and strengthening beliefs in personal capacities and we implicitly involve social persuasion.

According to Bandura (1997), verbal or social persuasion concerns the information that the individual receives from others about his/her abilities. Vicarious experiences, on the other hand, constitute an effective tool in promoting self-efficacy, so that such beliefs can change based on the observation of other people's skills, who may come to exercise the role of model and with which comparison is established based on one's own achievements.

In this perspective, we not only learn from direct experience, but we also acquire knowledge and attitudes from observation - and it occurs at any stage of life. Therefore, vicarious experiences result from behaviors and knowledge that come from the observation of other people acting. Notwithstanding, it is necessary for the observer to identify the observed one as someone similar in relation to age, gender, educational level, among other aspects, because the greater the similarity between both, the greater the effects on the spectator's self-efficacy, so that these effects can be good or bad, according to the levels of effort and success/ failure (Bandura, 1997).

Vicarious learning makes it possible to acquire new behavior without the need for rehearsals, which protects us from the risk of making potentially disastrous mistakes (Bandura, 1997). In addition, it provides us evidence that certain fears are unfounded and persuade us to abandon preconceived ideas and to act on what has been identified (Bandura \& Barab, 1973).

According to Navarro (2007), vicarious experiences can consist of both direct and indirect observations through video recordings (symbolic modeling), and if the model verbalizes their thinking and the strategies they use, it will potentiate their influence, especially in the development of cognitive abilities.

Another point that favors the use of vicarious experiences is the multiplicity and diversity of the models observed, that is, observing multiple models performing a certain task is more potent than being restricted to only one. Similarly, observing multiple models in different tasks brings more benefits than observing a single model performing different tasks (Navarro, 2007). The motivational effects generated by modeling cause the observer to create self-imposed performance demands and self-criticisms for lack of courage (Bandura \& Barab, 1973).

While reviewing writings about teacher self-efficacy, Martins and Chacon (2019) identified that the studies are, in their majority, only intended to measure the levels of self-efficacy presented. Likewise, Labone (2004) shows that correlational studies, of a quantitative nature, are predominant; their purpose is to portray the causes of these beliefs and their effects on teachers' performance. On the other hand, Bzuneck (2008) highlights the relevance of the studies with an intervention nature aimed at the growth of the beliefs of self-efficacy. This study aimed to investigate whether training courses for inclusive practices that involve sources of self-efficacy produce effects on teacher selfefficacy. More specifically, the sources involved were vicarious experiences and social persuasion.

\section{Method}

This research has a quasi-experimental design and uses the test-retest method, which consists of using the same test at different times, conserving the population, which allows to verify and to analyze possible correlations between these measures that have diversified over time (Bisquerra, Sarriera \& Martinez, 2007).

\section{Participants}

We announced, in public schools in Corumbá and Ladário, in Mato Grosso do Sul, Brazil, the opening of enrollment for 60 places in two training courses in "Pedagogical practices in inclusive education", related to this research. Based on the interest of teachers, this study involved 36 teachers who met the following inclusion criteria: to work in Elementary School 1 in public schools and to have graduation in Pedagogy. The teachers who did not meet these criteria entered the waiting list for future training. The participants were comprised into two groups: Group A (22) and Group B (14), made up mostly of women ( $95.45 \%$ and $92.86 \%$, respectively).

Most of the teachers in Group B are between the ages of 30 and 39 years old $(42.86 \%)$, followed by those who are between 40 and $49(28.57 \%)$, while there is a similar distribution between teachers from 30 to 39 years old (36.36\%) and those from 40 to 49 (36.36\%) in Group A. As for the teaching experience time, $50 \%$ of the participants from both groups were in the range of one to five years of professional activity.

\section{Instruments}

Escala de Eficácia Docente para Práticas Inclusivas (EEDPI): instrument translated and submitted to crosscultural adaptation to Brazilian reality, originally named Teacher Efficacy for Inclusive Practices (TEIP) Scale (Sharma, Loreman \& Forlin, 2012) and validated with 609 teachers from Canada (130), Australia (107), China (97) and India (275), with Cronbach's Alpha coefficient of 0.89 . The Brazilian version contains 16 statements that address educational strategies that promote inclusion, work together with family members and other professionals, and strategies for teaching and managing behavior in the classroom. Applied to a sample of 308 teachers, it presented a Cronbach's Alpha coefficient of 0.90 . The Likert scale presents six alternatives for each item: strongly disagree, disagree, partially disagree, partially agree, agree and strongly agree and your score ranges from 16 to 96 . In this study, we used the adapted versions focused on giftedness 
(EEDPI-AH/SD) and intellectual disability (EEDPI-DI) (Martins \& Chacon, 2020).

Observation Protocol for Inclusive Educational Situations: instrument that has 13 items and three answer options: yes, no and does not apply, which are converted into scores (respectively, 1, -1, 0) and the situations that add up to positive total scores are considered inclusive. The protocol resulted from a literature review that involved the analysis of 60 productions about school inclusion in order to identify parameters to identify successful educational inclusion situations, that is, those in which the special education public student is guaranteed the conditions of effective participation, learning and social interaction. It is worth clarifying that participating effectively goes beyond being physically present in the environment, developing tasks disconnected from the group or assuming the role of spectator; it requires the insertion of the student in the same activities developed by the class, even if they contain adaptations.

\section{Procedure}

Data collection. The intervention occurred through the development of two training courses that involved the analysis of vicarious experiences, presented through videos with footage of real situations of successful school inclusion, that is, classroom situations in which teachers promote the social interaction and the effective educational participation among the target students of Special Education and others, with the appropriate adaptations to the peculiarities of those, aiming at the promotion of learning and development.

Considering that vicarious experiences bring more satisfactory results to the extent that there is an identification between the observers and the observed, the filming integrated to the courses portrayed teachers with the same characteristics of the participants: graduated in Pedagogy, teaching in regular classrooms of Elementary School 1 in public schools of the cities of Corumbá and Ladário, in the state of Mato Grosso do Sul, Brazil. These records were made in 12 different classrooms and submitted to the analysis of experts in the Special Education area. Of the 19 filming sessions (average time of 44 minutes), in 15 of them the success of the practices registered based on the Protocol for Observation of Inclusive Educational Situations was verified. It is noteworthy that this instrument was used both by the specialists who selected the videos with successful inclusive educational situations that integrated the training, and by the teachers who watched these videos during the training.

The courses were called "Pedagogical Practices in Inclusive Education: Intellectual Disability" and "Pedagogical Practices in Inclusive Education: Giftedness", the first one was offered for Group A and the second one for Group B.

Each course lasted about two months, with an interval of two weeks between the end of one and the beginning of the other, both with ten three-hour meetings, which took place in the evening, varying from two to three times a week.

The themes were organized taking into account that inclusive education requires that teachers have conceptual knowledge regarding the fundamentals of inclusion, definitions, and characteristics of students; pedagogical knowledge that allows them to identify and assess the students' needs and to use strategies that enable their learning and social interaction; skills to work collaboratively (Sharma, Loreman \& Forlin, 2012), mainly with families - important partners for the accomplishment of students' success in school (Zafani \& Omote, 2016).

The meetings began with a case study related to the day's topic, followed by theoretical-practical discussions, and finished with a video exhibition of a successful inclusive educational experience, which was collectively analyzed and discussed, based on an Inclusive Education Observation Protocol. The aim was to provide an adequate environment for dialogue, reflection and exchange of experiences among the members of the groups. Therefore, the participants were exposed to a variety of symbolic models throughout the interventional sessions, in the same way that the acquisition of new knowledge and their socialization, together with reflections and sharing of ideas for the resolution of problem situations present in inclusive context, it created a climate of valorization of individual knowledge and experiences by the group, implicitly involving social persuasion.

Graham (2010) states that the main advantage of case studies methodology for learning is to be guided by questions, rather than answers, which require students to comprehensively understand the situation analyzed so that they are able to identify challenges, resume theoretical knowledge, and resolve conflicts in the search for suitable solutions. As for the display of videos, this was how participants were brought into contact with vicarious experiences regarding successful inclusive practices. The episodes, after being edited in the Movie Maker software, had, on average, 15 minutes, with the shortest duration being ten minutes and the longest, 25 minutes.

Data analysis. The analyses were held after the end of the intervention and focused on the results of the application of the instruments: EEDPI-AH/SD and EEDPI-DI, before and after the training.

For each participant, an individual score was assigned at all times in which he/she completed the EEDPI. Group A completed the scale, in its version for intellectual disability, on two occasions: during the enrollment and at the end of the training course (Pre-test and Post-test). Group B completed the version for giftedness in three situations: during the enrollment, in the first day of the course (two months after enrollment) and in its closure (Pre-test 1, Pre-test 2 and Post-test). The normality assumptions were evaluated with the Shapiro-Wilk test, by which the null hypothesis was rejected, in order to assume the non-normality of the distribution (Marôco, 2018).

We analyzed the results of the EEDPI statistically, for verifying the equivalence between the groups, through the Mann-Whitney test, which evaluates whether independent groups come from the same population (Bisquerra, Sarriera \& Martínez, 2007). There was no significant difference at the beginning of the research. This test was once again used to compare the groups in other stages of the investigation. 
The significance of intragroup differences was also analyzed using the Wilcoxon test in the various stages of the research. This is a non-parametric median contrast test, which attributes greater weight to the large differences between each pair of scores (Bisquerra at al., 2007). The level of significance of $5 \%(0.05)$ was considered acceptable, to reject the null hypothesis in the application of statistical tests.

\section{Ethical Considerations}

This study was approved by the Ethics Committee of the College of Philosophy and Sciences, Universidade Estadual Paulista "Júlio de Mesquita Filho", Marília Campus (Opinion No. 1.299.765, CAAE No. 47297315.9.0000.5406). The study was developed on the premises of a public university; all participants signed a Free and Informed Consent Term (FICT) after they were informed about the objectives and procedures of the study. The participants agreed with the voluntary nature of their participation, which can be terminated at any time, as well as with the guarantee of anonymity, with the unpredictability of the risks and with the publication of the results.

\section{Results}

Groups A and B took the Pre-test, from the completion of the EEDPI (gifted version or intellectual disability, according to the training to be performed) at the same time on the date of enrollment in the intended course. Group A began its training immediately afterward, performing the post-test at the end of the course, which lasted ten meetings in about two months. At that moment, Group B performed Pre-test 2 and began its training, completing the Post-test at the end of the training.

The total score of the scales applied could range from 16 to 96 . Group A had a minimum score of 64 and a maximum of 84 in the pre-test, with a median of 69.50 (quartile 1 of 67.25 and quartile 3 of 79.25), mean of 72.18 and standard deviation of 6, 61. In the post-test (after training), it presented a minimum of 66, a maximum of 93, a median of 77 (quartile 1 of 73.75 and quartile 3 of 84.00), mean 78.41 and standard deviation of 6.53 . It is noticed that the score obtained by Group A in the Post-test is higher than that obtained during the Pre-test. In order to know the significance of the changes, we made intra-group comparisons, which correspond to the comparison of each group with you, during the different stages of the research. For this, we used the Wilcoxon test. When comparing Group A's results obtained during the Pre-test and the Post-test, we found a statistically significant difference $(p<0.001)$, which points to the increase of the teachers' self-efficacy after training.

As for Group B, there is a drop in the score of Pre-test 2 in relation to Pre-test 1 , carried out in an interval of two months, since it presented a minimum of 60 , maximum of 88 , median of 70.50 (quartile 1 of 65.50 and quartile 3 of 81.25) and a mean of 72.71 (standard deviation of 9.47) in Pre-test 1; in Pre-test 2 the minimum was 44, the maximum was 88 , the median, 68.50 (quartile 1 of 62.25 and quartile 3 of 75.25) and the mean, 68.21 (standard deviation of 11,36 ). However, when comparing the data from Pre-test 1 and Pre-test 2, a statistically insignificant difference was obtained $(p=0.13)$, which indicates that the self-efficacy of these participants did not change significantly before the course.

In its Post-test, Group B had a minimum of 49, a maximum of 93, a median of 78 (quartile 1 of 66.00 and quartile 3 of 88.00) and a mean of 75.36 (standard deviation of 13.16). When comparing these results with those of Pre-test 2 , there was a statistically significant difference $(p=0.04)$ that attests the change in the self-efficacy of the members of Group B - which was amplified as a result of the training reaffirming the results already verified in the analysis of the data of Group A, showing that the interventions caused the strengthening of the beliefs in teacher self-efficacy.

Nevertheless, we aimed to confirm the positive results of the training obtained in the intragroup comparisons, analyzing the significance of the differences in the scores between the Groups during the investigation, through the Mann-Whitney test.

Groups A and B performed the pre-test simultaneously. When we calculated the difference between the groups, at the time of the pre-test, it was not statistically significant $(p=0.95)$, allowing us to understand that the groups were equivalent to the self-efficacy presented when we started the study for the inclusion of students with intellectual disabilities and giftedness.

After two months, Group B, which had not yet participated in the training, performed Pre-test 2. When comparing the results of Pre-test 2 of Group B with the Pre-test of Group A, we noticed the equivalence between groups $(p=0.23)$, that is, both started the training process with a similar level of self-efficacy, which proves, furthermore, that there was no external event or influence that significantly altered Group B self-efficacy during the period in which it awaited the beginning of the course.

Considering that both groups presented approximate self-efficacy levels, before being submitted to the intervention, we compared Group A's score in the Post-test with the Group B's score, prior to the course, to verify if the training was efficient enough to differentiate them as to the self-efficacy exhibited. At this moment, Group B assumes the role of control group over Group A. When analyzing the difference between Group B Pre-test 2 (without training) and Group A Post-test (after training), we obtained a statistically significant difference $(p=0.003)$, since Group A's score, after exposure to the models, was higher than that of Group B in Pre-test 2, while not participating in the training process, noting that the teacher education course based on the inseparability between theory and practice, which involved vicarious experiences and social persuasion, was responsible for the difference in the levels of self-efficacy of the participants in Group A, and demonstrating that the course on intellectual disability positively affected teachers' self-efficacy for inclusive practices. 
Finally, we compared the results of the Group A Post-test with Group B Post-test, both carried out at the end of the courses. Facing this comparison, there is a difference that is not statistically significant ( $p=0.64)$, which means that, after attending the training course on giftedness, Group B returned to be equivalent to Group A, which had taken part in the course on intellectual disability, in relation to teacher self-efficacy for inclusive practices - that is, the courses made the teachers of both groups present a greater belief in their abilities to include students with intellectual disability or giftedness.

\section{Discussion}

The results of the statistical analysis demonstrate the effectiveness of teacher education, based on vicarious experiences and social persuasion, in the strengthening of teacher self-efficacy to work with inclusion. The theoretical-practical contents stated and discussed brought essential knowledge for teaching in diversity, so as to contribute to the development of new skills, that have been ratified by the collective; on the other, the modeling of successful inclusive educational situations has provided vicarious experiences, whose effects on self-efficacy derive from both the acquisition of skills through observation, as well as the increase of confidence in one's own abilities, triggered by the model's influences in terms of predictability and controllability - that is, the prediction of success from the use of intentional actions, believing to have the same capabilities as the one being observed (Bandura, 1997).

The use of video vicarious experiences was proven to be effective in the study of Bandura and Menlove (1968) when they used a technique also known as symbolic modeling in the treatment of children with kynophobia. This study revealed that the display of multiple models is more effective than that of a single model. Therefore, our choice to exhibit different models of teachers, including students with intellectual disabilities and giftedness, instead of doing several shots in the same class, is shown to be correct. It is inferred that the visualization of several colleagues developing inclusive pedagogical practices increases the possibilities that the observing teacher also feels capable of accomplishing them. On the other hand, when always visualizing the same model, one can conclude that even with unusual abilities.

Bandura (2008) highlights the relevance of vicarious experiences stating that cognitive representations transmitted through modeling serve as guides for producing skillful performances and as standards for making corrective adjustments in the development of behavioral proficiency. Modeling not only contributes to the acquisition of knowledge and skills, but also acts on the motivational aspects, because the observer is convinced that, if the model is capable, he/she also is (Bandura \& Barab, 1973).

Applying these teachings to the teaching role, it is understood that the observation of more effective models contributes to the observer teacher to acquire new competencies and reflect on their conceptions and ways of acting, modifying their practice, at the same time to the strengthening of their self-efficacy. However, it is important that the observer realizes a certain similarity between the performance capacity of the model and his own, which also applies to the personal attributes, indicating that the observation among peers tends to be more impacting than the visualization of the behavior of consultants or educators of other levels of education (Bandura, 1997; Labone, 2004). The justification for this necessary approximation is due to the fact that a professional of distinct training and acting in other contexts can be understood as someone who has knowledge, skills, and resources considered unattainable by the observer. Social persuasion - which, on its own, has limited effects - depends on the credibility that is attributed to those who emit it and on the coherence between what is verbalized and the real competence displayed (Bandura, 1997). Therefore, all participants started to have knowledge that allowed them to recognize and confirm the knowledge and skills, expressed by colleagues; such confirmation was expressed by the verbalization / gesturing of agreement and acceptance of ideas and opinions. This external validation, although less influential than vicarious experiences (Bandura, 1997), also contributes to strengthening confidence in individual capacities.

The similarity between the observers and the models was guaranteed in our investigation. The professionals had the same training while graduating in Pedagogy and working in public Elementary Education in the same cities - so they worked under very similar working conditions, many of whom had previously known each other. In this way, some participants commented on their previous knowledge about the dedication and competence of the observed models. The filming also allowed controlling the visualization of positive models, once the recordings were analyzed by judges, from the Inclusive Education Observation Protocol. The multiplicity of models has also been safeguarded since the effects of observing multiple models are larger than those produced by the observation of a single model (Bandura, 1997).

Based on Maibach and Flora (1993), Bandura (1997) asserts that symbolic modeling has greater impacts on selfefficacy than verbal instructions on appropriate strategies. If this modeling is accompanied by a cognitive test, that is, the symbolic representation of the performance of the model activity by the observer, the effects of the intervention are increased. In addition, if action is monitored and accompanied by instructive feedback, the conditions for identification and correction of inadequacies are broadened (Bandura, 2008).

Teacher self-efficacy is linked to the way the teaching and learning process is conducted, as well as to the way teacherstudent relationships are established, which play a key role in student motivation and achievement. In fact, teachers' beliefs about their teaching abilities are associated with the pedagogical strategies adopted, the decision making and the motivation they present (Navarro, 2007). In addition, Honnef and Costas (2012) warn that strictly theoretical training, which disregard the experiences of its participants, contribute little to the necessary changes in the prevailing pedagogical conceptions and strategies in the educational context. It is important to promote moments 
for reflections and group discussions, from the sharing of the experiences of the teaching staff.

When teachers share their successes, their difficulties and anguishes, they reveal strategies that have been successful or frustrating, seek to help each other, the sense of belonging is strengthened and the atmosphere becomes more positive.

It is pointed out that high teacher self-efficacy is a key ingredient to the success of inclusive education (Canabarro, Teixeira \& Schmidt, 2018; Sharma, Loreman \& Forlin, 2012). However, although it is extremely relevant to a good teaching practice, self-efficacy alone is not enough, because the actions accomplished will only achieve the desired results, as beliefs are accompanied by knowledge and skills (Bzuneck, 2017; Navarro, 2007), which reaffirms the importance of teacher education, since "knowledge and skills developed in training courses and continuing training have the potential, together with other conditions, to guarantee good results in teaching when the beliefs of self-efficacy are present" (Bzuneck, 2017, p. 705, free translation).

It should be noted that the review of national and international literature undertaken by Martins and Chacon (2019) found 74 papers among theses, dissertations and articles that related teacher self-efficacy and special education, only five of them developed in Brazil. When the authors crossed these results with the variable teacher education, they found 12 works, none of them developed in a national context. Among the international researches dedicated to investigating the relationship between self-efficacy, teacher training and special education, some analyzed exclusively theoretical training interventions (Almeida, Jameson, Riesen, \& McDonnell, 2016; Chao, Sze, Chow, Forlin, \& Ho, 2017), while others also covered practical experiences (Shani \& Hebel, 2016; Tindall, Culhane, \& Foley, 2016), but none of them involved vicarious experiences. Although the results are indicated as positive or moderately positive, there are studies in which direct experience has negatively influenced the effects of training (Sharma \& Sokal, 2015). In this sense, although the most powerful source of self-efficacy consists of domain experiences, which derive from direct experiences, when they are not successful, they can impair the sense of self-efficacy (Bandura, 1997), which highlights the potential of vicarious experiences, which occupy the second position regarding the influence of self-efficacy sources and can be intentionally controlled by symbolic modeling.

Thus, in relation to the courses that were developed, aiming to strengthen teacher self-efficacy for inclusive practices in this research, it is believed that the teachers' experiences are of paramount importance for the training process, as this only makes sense when it causes critical reflection on the practice; this, in turn, requires theoretical foundation. Therefore, it is emphasized the inseparability between theory and practice, which must be valued in the training of teachers. In this sense, the contributions of sources of self-efficacy in teacher education to inclusive practices are emphasized with a view to acquiring new knowledge, arising from collective, critical and reflective analysis and discussion about educational performance. Although the emphasis was on vicarious experiences, it is believed that they were not the only ones responsible for the increase in teachers' self-efficacy, but a catalyst component of the process that included the construction of theoretical and practical knowledge, sharing of knowledge and experiences, analysis and joint reflection of educational situations, in order to also enable social persuasion.

In order to analyze the implications of the isolated effects of vicarious experiences, further investigations are needed, with a different design than that developed and a control group. In addition, it is suggested to replicate this study in other contexts and populations, as well as to diversify the techniques and methodological procedures. As a limitation of this study, it is pointed out the absence of postponed Post-test, which would indicate the maintenance or not of the effects on teacher self-efficacy after a certain time has elapsed.

\section{Referências}

Almeida, C. M., Jameson, J. M., Riesen, T., \& McDonnell, J. (2016). Urban and rural preservice special education teachers' computer use and perceptions of self-efficacy. Rural Special Education Quarterly, 35(3), 12-19. doi:10.1177/875687051603500303

Bandura, A. (1997). Self-efficacy: The exercise of control. New York, NY: Worth.

Bandura, A. (2008). A evolução da teoria social cognitiva [The evolution of social cognitive theory]. In A. Bandura, R. G. Azzi, \& S. Polydoro, Teoria social cognitiva: Conceitos básicos [Cognitive social theory: Basic concepts] (R. C. Costa, Trans., pp. 15-41). Porto Alegre, RS: Artmed.

Bandura, A., \& Barab, P. G. (1973). Processes governing disinhibitory effects through symbolic modeling. Journal of Abnormal Psychology, 82(1), 1-9. doi:10.1037/h0034968

Bandura, A., \& Menlove, F. L. (1968). Factors determining vicarious extinction of avoidance behavior through symbolic modeling. Journal of Personality and Social Psychology, 8(2 Pt. 1), 99-108. doi:10.1037/h0025260

Barbosa, M. O. (2018). O transtorno do espectro autista em tempos de inclusão escolar: $\mathrm{O}$ foco nos profissionais de educação [Autism spectrum disorder in school inclusion times: Focus on education professionals]. Revista Educação Especial, 31(61), 299-310. doi:10.5902/1984686X24248

Bisquerra, R., Sarriera, J. C., \& Martínez, F. (2007). Introdução à estatística: Enfoque informático com o pacote estatístico SPSS [Introduction to statistics: Computer-based approach to the SPSS statistical package]. Porto Alegre, RS: Artmed.

Bzuneck, J. A. Prefácio [Preface]. (2008). In A. Bandura, R. G. Azzi, \& S. Polydoro, Teoria social cognitiva: Conceitos básicos [Cognitive social theory: Basic concepts] (pp. 1114). Porto Alegre, RS: Artmed.

Bzuneck, J. A. (2017). Crenças de autoeficácia de professores: Um fator motivacional crítico na educação inclusiva [Teacher self-efficacy beliefs: A critical motivational factor in inclusive education]. Revista Educação Especial, 30(59), 697-708. doi:10.5902/1984686X28427 
Canabarro, R. C. C., Teixeira, M. C. T. V., \& Schmidt, C. (2018). Translation and transcultural adaptation of the selfefficacy scale for teachers of students with autism: Autism Self-Efficacy Scale for Teachers (Asset). Revista Brasileira de Educação Especial, 24(2), 229-246. doi:10.1590/s141365382418000200006

Capellini, V. L. M. F., \& Zerbato, A. P. (2019). O que é ensino colaborativo? [What is co-teaching?]. São Paulo, SP: Edicon.

Chao, C. N. G., Sze, W., Chow, E., Forlin, C., \& Ho, F. C (2017). Improving teachers' self-efficacy in applying teaching and learning strategies and classroom management to studentes with special education needs in Hong Kong. Teaching and Teacher Education, 66, 360-369. doi:10.1016/j.tate.2017.05.004

Faria, P. M. F., \& Camargo, D. (2018). Teacher's emotions in relation to the school inclusion process: A systematic review. Revista Brasileira de Educação Especial, 24(2), 217-228. doi:10.1590/s1413-65382418000200005

Garcia, R. M. C. (2016). Educação especial na perspectiva inclusiva: Determinantes econômicos e políticos [Special education at inclusive perspective: Economic and politics determinants]. Comunicações, 23(1), 7-26. doi:10.15600/2238-121X/comunicacoes.v23nespp7-26

Graham, A. (2010). Como escrever e usar estudos de caso para ensino e aprendizagem no setor público [How to write and use case studies for teaching and learning in the public sector]. Brasília, DF: ENAP.

Heredero, E. S. (2016). Inclusão e formação de professores [Inclusion and teacher education]. In R. U. C. Carneiro, M. J. C. Dall'Acqua, \& P. M. Caramori (Eds.), Educação especial e inclusiva: Mudanças para a escola e sociedade [Special and inclusive education: Changes for school and society] (pp. 65-78). Jundiaí, SP: Paco Editorial.

Honnef, C., \& Costas, F. A. T. (2012). Formação para a educação especial na perspectiva inclusiva: O papel das experiências pedagógicas docentes nesse processo [Training for special education in an inclusive perspective: The role of teaching pedagogical experiences in this process]. Revista Reflexão e Ação, 20(1), 111-124. doi:10.17058/rea.v20i1.2359

Labone, E. (2004). Teacher efficacy: Maturing the construct through research in alternative paradigms. Teaching and Teacher Education, 20(4), 341-359. doi:10.1016/j. tate.2004.02.013

Lei No. 9.394, de 20 de dezembro de 1996. (1996, 23 de dezembro). Estabelece as diretrizes e bases da educação nacional [Establishes the guidelines and bases of national education]. Diário Oficial da União, seção 1. Retrieved from https://pesquisa.in.gov.br/imprensa/jsp/visualiza/index.jsp? data $=23 / 12 / 1996 \&$ jornal=1\&pagina=1\&totalArquivos $=289$

Maibach, E., \& Flora, J. A. (1993). Symbolic modeling and cognitive rehearsal: Using video to promote AIDS prevention self-efficacy. Communication Research, 20(4), 517-545. doi:10.1177/009365093020004002
Marôco, J. (2018). Análise estatística com o SPSS Statistics [Statistical analysis with SPSS Statistics] (7th ed.). Perô Pinheiro, Portugal: ReportNumber.

Martins, B.A., \& Chacon, M. C. M. (2019). Autoeficácia docente e Educação Especial: Revisão da produção de conhecimento nacional e internacional com ênfase na formação de professores [Teacher self-efficacy and Special Education: National and international knowledge production review with emphasis in teacher education]. Revista Educação Especial, 32(1), 1-22. doi:10.5902/1984686X35883

Martins, B. A., \& Chacon, M. C. M. (2020). Teacher Efficacy for Inclusive Practices (TEIP) scale validation. Revista Brasileira de Educação Especial, 26(1), 1-16. doi:10.1590/ s1413-65382620000100001

Matos, S. N., \& Mendes, E. G. (2015). Demandas de professores decorrentes da inclusão escolar [Demands of teachers arising from school inclusion]. Revista Brasileira de Educação Especial, 21(1), 9-22. doi:10.1590/S141365382115000100002

Miranda, M. J. C., Dall'Acqua, M. J. C., Heredero, E. S., Giroto, C. R. M., \& Martins, S. E. S. O. (2013). Inclusão, educação infantil e formação de professores [Inclusion, early childhood education and teacher education]. Marília, SP: Oficina Universitária; São Paulo, SP: Cultura Acadêmica. Retrieved from https://www.marilia.unesp.br/Home/Publicacoes/aflivro_13_miranda.pdf

Navarro, L. P. (2007). Autoeficacia del professor universitário: Eficacia percebida e práctica docente [Self-efficacy of the university professor: Efficacy perceived and teaching practice] (2nd ed.). Madrid, España: Narcea.

Nozi, G. S., \& Vitaliano, C. R. (2017). Saberes de professores propícios à inclusão dos alunos com necessidades educacionais especiais: Condições para sua construção [Teachers' knowledge conducive to the inclusion of students with special educational needs: Conditions for their construction]. Revista Educação Especial, 30(59), 589-602. doi:10.5902/1984686X28080

Shani, M., \& Hebel, O. (2016). Educating towards inclusive education: Assessing a teacher-training program for working with pupils with Special Educational Needs and Disabilities (SEND) enrolled in general education schools. International Journal of Special Education, 31(3), 1-23. Retrieved from https://eric.ed.gov/?id=EJ1120685

Sharma, U., Loreman, T., \& Forlin, C. (2012). Measuring teacher efficacy to implement inclusive practices. Journal of Research in Special Educational Needs, 12(1), 12-21. doi:10.1111/j.1471-3802.2011.01200.x

Sharma, U., \& Sokal, L. (2015). The impact of a teacher education course on pre-service teachers' beliefs about inclusion: An international comparison. Journal of Research in Special Educational Needs, 15(4), 276-284. doi:10.1111/1471-3802.12043 
Silva, J. C., \& Silva, M. M. (2015). Colaboração entre professores e autoeficácia docente: Que relações? [Collaboration between teachers and teacher self-efficacy: What relationships?] Revista Portuguesa de Educação, 28(2), 87-109. doi:10.21814/rpe.7733

Silva, R. M., \& Ribeiro, L. L. (2017). Permanências do modelo médico nos discursos dos professores de educação especial [Permanences of the medical model in the speeches of special education teachers]. Revista Educação, Arte e Educação, 13(1), 141-166. doi:10.5965/1984317813012017141

Tindall, D., Culhane, M., \& Foley, J. (2016). Pre-service teachers' self-efficacy towards children with disabilities: An Irish perspective. European Journal of Adapted Physical Activity, 9(1), 27-39. doi:10.5507/euj.2016.003

Tschannen-Moran, M., \& Hoy, A. W. (2001). Teacher efficacy: Capturing an elusive construct. Teaching and Teacher Education, 17(7), 783-805. doi:10.1016/ S0742-051X(01)00036-1

Zafani, M. D., \& Omote, S. (2016). Atribuições da família na percepção do professor [Family roles in the teacher's perception]. Journal of Research in Special Educational Needs, 16(1), 221-224. doi:10.1111/1471-3802.12285

Bárbara Amaral Martins is a Professor of the Universidade Federal de Mato Grosso do Sul, Corumbá-MS, Brazil.

Miguel Claudio Moriel Chacon is a Professor of the Universidade Estadual Paulista Júlio de Mesquita Filho, Marília-SP, Brazil.

\section{Authors' Contribution:}

All authors made substantial contributions to the conception and design of this study, to data analysis and interpretation, and to the manuscript revision and approval of the final version. All the authors take public responsability for content of the manuscript.

Associate editor:

Edna Maria Marturano

Received: Jul. 02, 2020

1st Revision: Sep. 10, 2020

Approved: Oct. 12, 2020

How to cite this article:

Martins, B. A., \& Chacon, M. C. M. (2021). Sources of teacher self-efficacy in teacher education for inclusive practices. Paidéia (Ribeirão Preto), 31, e3109.doi:https://doi.org/10.1590/1982-4327e3109 